\title{
GEOSTRATEGIA XI JINPINGA - OD SKROMNOŚCI DO GLOBALNEJ ASERTYWNOŚCI
}

Od czasu „ojca Chin republikańskich” Sun Yat-sena ${ }^{1}$ przywódcy chińscy marzyli o powrocie do potęgi, jaką Państwo Środka przez wieki, jeśli nie tysiąclecia, niewątpliwie było ${ }^{2}$. Takich mocnych Chin chciał rządzący dyktatorsko Czang Kaj-szek ${ }^{3}$, chociaż - podobnie jak Sun - swoich ambitnych planów nie zdołał spełnić. Pocesarskie i postimperialne Chiny najpierw były szarpane konfliktami wewnętrznymi i wojnami lokalnych wojskowych watażków (junfa - warlords) ${ }^{4}$, a następnie walczyły z inwazją japońską ${ }^{5}$ i ponownie popadły w konflikt wewnętrzny, tym razem prawdziwą i brutalną wojnę domową między rządzącym dotychczas Guomindangiem Chińską Partią Narodową a wyłaniającą się jako nowa siła Komunistyczną Partią Chin (KPCh) z charyzmatycznym Mao Zedongiem na czele.

Ten nowy wódz po dojściu do władzy 1 października 1949 r. i wypędzeniu Czang Kaj-szeka na Tajwan też nie ukrywał, że marzy o wielkich Chinach. Jednakże i jemu nie do końca się powiodło. Zrealizował natomiast to, co nie udawało się poprzednikowi - poza Tajwanem i Hongkongiem oraz Makau scalił chińskie ziemie, a swoją wolę narzucił też obszarom niechińskim, jak Tybet czy Xinjiang. Dlatego na bramie Tiananmen, w samym sercu Pekinu do dzisiaj wisi jego portret, po pierwsze jako założyciela nowej dynastii spod znaku KPCh, a po drugie jako tego, który zjednoczył i wybawił Państwo Środka z trudnego okresu chaosu

1 B. Góralczyk, Sun Yat-sen. Misjonarz, rewolucji, Warszawa 2013; J. Rowiński, Ewolucja polityki zagraniçnej Chińskiej Republiki Ludowej (1949-2011) [w:] Wielkie przemiany w Chinach. Próba bilansu reform Deng Xiaopinga, red. K. Gawlikowski, M. Lawacz, Warszawa 2012, s. 224.

2 Według znanych i cenionych badań Agnusa Maddisona przed niesławnymi w Chinach wojnami opiumowymi Państwo Środka nadal dawało światu $1 / 3$ jego PKB, podobnie było też w poprzednich stuleciach. A. Maddison, Chinese Economic Performance in the Long Run, second edition, revised and updated, 960-2030AD, Paris 2007, s. 44.

3 Znakomita biografia w języku polskim: J. Polit, Pod wiatr. Czang Kaj-šek 1887-1975, Kraków 2008.

4 Ibidem, s. 71-77; szerzej: J. Fenby, Cbiny. Upadek i narodżiny wielkiej potegi, Kraków 2009, s. 221-243.

5 Najszersze studium w języku polskim: J. Polit, Gorzki triumf. Wojna chińsko-japońska 19371945, Kraków 2013. 
i walk wewnętrznych, znamiennie określanego tam mianem stu lat narodowego poniżenia (bai nian guochi) ${ }^{6}$.

\section{Deng Xiaoping i strategia low profile}

Woluntarystyczny Mao, z ducha i litery rewolucjonista, nie osiagnął swych ambitnych mocarstwowych celów, czego dowodem jest fakt, że udział chińskiego PKB w światowym w „epoce Mao” (1949-1976) nie tylko nie wzrósł, ale nawet spadł z 5,2\% do 4,9\% w 1978 r. $^{7}$ Miast zostawić po sobie Chiny narzucające światu własna formułę reżimu rewolucyjnego, jak chciał, po odejściu we wrześniu 1976 r. Mao zostawił Chiny nadal agrarne (84\% ludności na wsi), zacofane, autarkiczne i odizolowane, a po ciężkich doświadczeniach (i głodzie!) Wielkiego Skoku (1958-1960) ${ }^{8}$ i traumie rewolucji kulturalnej (1966-1976) wręcz cierpiące i obolałe, wymagające długiej kuracji na scenie wewnętrznej?

Tragedia rewolucji kulturalnej osobiście dotknęła wielu polityków z samego wierzchołka władzy, w tym dotychczasowego sekretarza generalnego Komitetu Centralnego KPCh, w istocie trzecią osobę w hierarchii, Deng Xiaopinga, sekowanego nawet jako „druga osoba w państwie, kroczaca kapitalistyczna drogą” (pierwszą był przewodniczący Chińskiej Republiki Ludowej Liu Shaoqi, zamęczony i zakatowany na śmierć w 1969 r.). Deng trafił - z woli Mao - na kilka lat na chińską wieś, a tam - jak już wiemy - jako ciągle przekonany komunista, ale też pragmatyk, a nie ideolog ${ }^{10}$, zadał sobie podstawowe pytanie: dlaczego Chińczycy w ChRL sa tak biedni, podczas gdy ich krajanie w Hongkongu, na Tajwanie czy w rozległej chińskiej diasporze tacy bogaci. A gdy je zadał, stał się rewizjonistą - nie chciał już

${ }^{6}$ Znakomita analiza: Zheng Wang, Never Forget National Humiliation. Historical Memory in Chinese Politics and Foreign Relations, New York 2012.

7 A. Maddison, Chinese Economic Performance..., s. 44.

8 Klasyczne studium na ten temat jest dostępne po polsku: F. Dikötter, Wielki głód. Tragične skutki polityki Mao 1958-1962, przeł. B. Gadomska, Wołowiec 2013. Autor ocenia, że ofiar głodu mogło być nawet $45 \mathrm{mln}$ (s. 11).

9 Dochody na głowę mieszkańca w ChRL w 1978 r., u progu reform, wynosiły zaledwie 313 juanów (ok. 182 USD według ówczesnego oficjalnego kursu). B. Tálas, Economic Reforms and Political Reform Attempts in China 1979-1989, Berlin-New York-London 1991, s. 61. Dane te potwierdzaja autorzy chińscy: Li Tieying podaje, że w 1978 r. dochody per capita mieszkańców ChRL wynosily 230 USD. Li Tieying, Reforma Chin: dla upamietnienia 30 rocznicy polityki reform i otwarcia [w:] Reformujac Chiny. Doswriadcrenia i wnioski, red. Zhou Dongtao, przeł. M. Ciecierski, Toruń 2012, s. 7.

10 Był znany od 1962 r. z maksymy: „Nieważne, czy kot jest biały, czy czarny, ważne, żeby łowił myszy”. Według jednej z najwnikliwszych i najlepszych biografii Denga po raz pierwszy użył on tej formuły w czerwcu 1962 r., sięgając po podobną z jego rodzinnej prowincji Sichuan: „Nieważne, czy kot jest czarny, czy żółty, bo jeśli łapie myszy, to jest dobrym kotem”, A.V. Pantsov, S.V. Levine, Deng Xiaoping. A Revolutionary Life, Oxford 2015, s. 222. 
kontynuować rewolucyjnej linii Mao, w ramach której kluczowym ogniwem miała być walka klasowa.

Te traumatyczne doświadczenia, podobnie jak wizyty zagraniczne u progu reform - przede wszystkim w Japonii, Singapurze i USA - uświadomiły Dengowi, jak bardzo zacofane są Chiny, co potwierdzał publicznie ${ }^{11}$. Toteż gdy ostatecznie doszedł do władzy pod koniec grudnia 1978 r., po niemal dwuletnim interregnum, w trakcie którego jego pragmatyzm ścierał się z poglądami następców Mao (krótka epoka Hua Guofenga), zaproponował zamianę walki klasowej w bój o modernizację, wzrost i postęp gospodarczy. Dość szybko, już latem 1979 r. odszedł od promowanej dotychczas strategii „czterech modernizacji”, przedłożonej niegdyś przez jego politycznego idola, byłego premiera Zhou Enlaia. Zdecydował się natomiast na faktycznie istniejącą do dziś, choć ostatnio słabiej widoczną, kampanię na rzecz gaige, kaifang, czyli wprowadził głęboka, prorynkową w duchu reformę gospodarczą oraz otworzył Chiny na świat, a przede wszystkim na kapitały napływające z kies Chińczyków zamorskich (bua qiao), począwszy od Hongkongu. Dowodem, że tak jest, było otwarcie pierwszych czterech stref gospodarczych, na których terenie pozwolono na eksperymenty z rynkiem i kapitalizmem, utworzonych - jakże znamiennie - w Shenzhen na granicy z Hongkongiem, Zhuhai na granicy z portugalskim Makau (Aomen) oraz w portach Xiamen i Shantou vis à vis Tajwanu.

Po poprzednich traumach i dewastacji, nie tylko gospodarczej, lecz we wszystkich dziedzinach, w tym w nauce i oświacie, paleta zadań na scenie wewnętrznej była tak obszerna, że na długo niemal całkowicie odsunęła cele $\mathrm{i}$ interesy na arenie zewnętrznej. Nie pozostawiono jedynie żadnych wątpliwości co do formuły jednych Chin, a więc tego, że Tajwan stanowi ich integralną część, czego dowodem była głośna swego czasu „Odezwa do rodaków na Tajwanie”, wystosowana 1 stycznia 1979 r. tuż po objęciu przez Denga pełni władzy ${ }^{12}$. Od tej chwili reformatorskie Chiny nigdy nie pozostawiały wątpliwości co do tego, że nadrzędnym celem ich dyplomacji, „głównym zadaniem narodowym” jest „ponowne zjednoczenie ojczyzny", chociaż środki i metody, jak do tego miałoby dojść, zmieniały się - raz sięgano po militarne, zwiększając liczbę dział wymierzonych w wyspę, innym razem, w miarę upływu czasu częściej, po środki polityczne oraz naciski ekonomiczne, handlowe i dyplomatyczne ${ }^{13}$.

11 E.F. Vogel, Deng Xiaoping And The Transformation of China, Cambridge, MassachusettsLondon 2011, s. 218.

12 Gao Taiwan tongbao shu - tekst i analiza w języku chińskim: http://baike.baidu.com/item/\% $\mathrm{E} 5 \% 91 \% 8 \mathrm{~A} \% \mathrm{E} 5 \% 8 \mathrm{~F} \% \mathrm{~B} 0 \% \mathrm{E} 6 \% \mathrm{~B} 9 \% \mathrm{BE} \% \mathrm{E} 5 \% 90 \% 8 \mathrm{C} \% \mathrm{E} 8 \% 83 \% 9 \mathrm{E} \% \mathrm{E} 4 \% \mathrm{~B} 9 \% \mathrm{~A} 6 / 521185$ 6 ?fr=aladdin (dostęp: 30.12.2016).

13 Szerzej: W.J. Dziak, K. Gawlikowski, Perspektyny normalizacji stosunków CbRL ₹. Tajwanem szanse $i$ zagrożenia [w:] Chiny w XXI wieku. Perspektywy rozwoju, red. W.J. Dziak, K. Gawlikowski, M. Lawacz, Warszawa 2012, s. 299-311. 
Nieco później skupiono się na innym ważnym celu, jakim było przywrócenie suwerennych praw nad Hongkongiem. Jego znaczna część, tzw. Nowe Terytoria stanowiące około 95\% powierzchni kolonii, była tylko dzierżawa, wymuszoną pod koniec XIX wieku na wówczas jeszcze cesarskich Chinach na mocy tzw. nierównoprawnych traktatów. Tutaj Deng, nie po raz pierwszy i nie ostatni, wykazał się wielka inwencją i dyplomatyczną zręcznością: zaproponował nieortodoksyjną formułę ,jeden kraj, dwa systemy/ustroje" 14 . Na jej mocy Hongkong po powrocie do macierzy przez jeszcze 50 lat (a więc do 1 lipca 2047 r.) ma zachować swój kapitalistyczny ustrój (mniej mówiono o demokracji, co z czasem miało odezwać się czkawka) ${ }^{15}$. Postawiło to negocjujących z Chińczykami Brytyjczyków na pozycjach z góry przegranych $^{16}$. Pod koniec grudnia 1984 r. ówczesna premier Margaret Thatcher udała się do Pekinu i tam podpisała dwustronną deklarację, jeden z dwóch podstawowych dokumentów, obok tzw. ustawy zasadniczej z 4 kwietnia 1990 r., na mocy których od 1 lipca 1997 r. Hongkong stał się autonomicznym regionem w ramach $\mathrm{ChRL}^{17}$ (już 20 grudnia 1999 r. ten eksperyment powtórzono z mniejszym i mniej znaczącym Makau). Dość szybko okazało się jednak, że wbrew pierwotnym obawom nastapiła nie tyle komunizacja kolonii ${ }^{18}$, ile proces dokładnie odwrotny, to znaczy honkongizacja, a więc urynkowienie i narzucenie kapitalistycznych reguł w ChRL.

Od początku był to jednak proces powolny i stopniowy, a zarazem specyficzny wyłącznie dla Chin. Deng, będąc pionierem reform w ramach realnego socjalizmu (Michaił Gorbaczow wyszedł ze swoim programem dopiero po marcu 1985 r.) i nie mając żadnych wypracowanych strategii ani na świecie (sięgano częściowo po doświadczenia ówczesnych Węgier i Polski) ${ }^{19}$, ani u siebie (inteligencję w ramach „dzie-

14 Deng Xiaoping, Chinska droga do socjalizmu, Warszawa 1988, s. 274-283; krytyczna analiza, E.F. Vogel, Deng Xiaoping..., s. 477-522.

15 Przykładem protesty społeczne, w tym głośna rewolucja parasolkowa z 2014 r.

16 Szerzej zob. wspomnienia głównego brytyjskiego negocjatora: P. Cradock, Experiences of China, London 1994.

17 J. Rowiński, W. Jakóbiec, System konstytucyjny i przedstawicielski Specjalnego Autonomicznego Regionu ChRL Hongkongu, Warszawa 2012. Ci sami autorzy w 2006 r. szczegółowo przedstawili też System konstytucyjny Makau.

18 Zob. relacje na ten temat wybitnego reportera włoskiego, który tuż przed przejęciem suwerennych praw od Brytyjczyków był na terenie kolonii: T. Terzani, $W$ Aæji, przeł. J. Wajs, Warszawa 2011, s. 490-517.

19 J. Kornai, Siła idei. Zapiski z intelektualnej podróży, przeł. J. Okuniewski, S. Szymański, Warszawa 2008. Ten wybitny węgierski ekonomista po raz pierwszy wyjechał do Chin latem 1985 r. i wtedy, jak pisze: „(..) w rozmowach z chińskimi ekonomistami i biznesmenami czułem, że w pewnym sensie byłem w Chinach u siebie w domu, niezależnie od historycznych i kulturowych różnic. Wszystkie zjawiska, które się ujawniły, troski i niedostatki były mi znane” (s. 369). To tylko dowód na stawianą w tym opracowaniu tezę, że w pierwszej dekadzie zmian Chiny reformowały realny socjalizm, a dopiero po 1992 r. zamieniły się, na wzór azjatyckich tygrysów, w państwo prorozwojowe (developmental state). Wnikliwa analiza tego ostatniego, postsocjalistycznego modelu zob. A. Bolesta, China and Post-Socialist Development, London 2015. 
sięcioletniego chaosu rewolucji kulturalnej" niemal doszczętnie wytępiono), sięgnął raz jeszcze do skarbnicy ludowych mądrości. To z nich brała się jego wcześniejsza maksyma o kotach, a teraz doszła druga, na której oparł strategię państwa: „iść przez rzekę, czując kamienie pod stopami”" (moz̧he shitou guo he $)^{20}$. Innymi słowy, celem było to, by przejść na drugi brzeg, do modernizacji i nowoczesności. Ponieważ jednak nikt dotychczas czegoś podobnego nie robił, i to na tak wielką skalę, więc dodał jeszcze jedną formułę, shishi qiu shi, a więc „poszukiwać prawdy w faktach”21. $\mathrm{Na}$ tej podstawie, ostrożnie i powoli, zamierzał budować przyszłość państwa. Tak narodziła się strategia gradualizmu w polityce wewnętrznej oraz prowadzonym procesie modernizacji i reform, wszystko jednak w ramach obowiązującego systemu politycznego z KPCh na czele. Wówczas, w pierwszej dekadzie zmian, reformowano komunizm, nie porzucając go na rzecz globalizmu czy gospodarki kapitalistycznej, choć urynkowienie chińskiej gospodarki bezustannie rosło. Nie była to więc jeszcze, podkreślmy to mocno, głęboka systemowa transformacja.

Deng, który mimo swego pragmatyzmu odszedł (w kwietniu 1997 r.) z tego świata jako przekonany komunista, nigdy nie pozostawiał wątpliwości co do tego, że Chiny mają utrzymać system socjalistyczny, tyle że nie hurarewolucyjny, jak za Mao. Nie zawahał się, gdy u samego progu reform natknął się na polityczny i ideologiczny ferment. Nie tylko kazał uwięzić najgłośniejszego dysydenta, Wei Jingshenga, domagającego się „piątej modernizacji - demokratyzacji”22 i zamknąć głośną „ścianę demokracji” ${ }^{23}$, ale w ślad za tym podyktował Chinom - obowiązujące do dziś i wpisane do preambuły Konstytucji - „,ztery podstawowe zasady”. Zgodnie z nimi w ChRL należy: 1) trzymać się socjalistycznej drogi, przestrzegać 2) dyktatury (proletariatu), 3) kierowniczej roli KPCh oraz 4) zasad marksizmu-leninizmu i myśli

${ }^{20}$ W tej kwestii toczy się nierozstrzygnięty spór. Powszechnie przypisuje się jej autorstwo Dengowi, co nie jest prawda. Długo przypisywano jej wynalezienie pierwszemu premierowi okresu reform Zhao Ziyangowi, który najchętniej posługiwał się tym mottem. Ostatnio dowodzi się jednak, że po raz pierwszy użył go w grudniu 1978 r. strateg gospodarczy Chen Yun. F. Godemont, Czego chcq Chiny?, przeł. K. Sarek, Warszawa 2016, s. 82, 83. O implementacji tej maksymy: B. Góralczyk, Przebudzenie smoka. Powrót Chin na scene globalna, Warszawa 2012, s. 50, 51.

${ }^{21}$ Wywodzi się ona jeszcze z czasów dynastii Han. Pierwszy sięgnął do niej Mao Zedong. Pragmatycy i reformatorzy po 1978 r. chętnie do niej nawiązywali. Omówienie w języku chińskim: http://baike.baidu.com/item/\%E5\%AE $\% 9 \mathrm{E} \% \mathrm{E} 4 \% \mathrm{BA} \% 8 \mathrm{~B} \% \mathrm{E} 6 \% \mathrm{~B} 1 \% 82 \% \mathrm{E} 6 \% 98 \% \mathrm{~A}$ F/36312?fr=aladdin (dostęp: 20.12.2016). Krytyczna analiza: D. Mierzejewski, Między pragmatyzmem a konfucjańska moralnościq. Dezideologizacja retoryki chińskiej polityki zagranicznej w okresie reform, Lódź 2013, s. 103.

22 Wei Jingsheng, The Courage to Stand Alone. Letters from Prison and Other Writings, London-New York 1998, s. 201-212.

23 Klasyczna już, najdokładniejsza dokumentacja tego ruchu na Zachodzie ze strony ówczesnego sekretarza Ambasady Brytyjskiej w Pekinie: R. Garside, Coming Alive. China After Mao, New York 1981, s. 212-335. 
Mao Zedonga ${ }^{24}$ (do których potem dodano jego własne). Inaczej ujmując, godzono się na reformy i eksperymenty w gospodarce, ale system polityczny miał zostać w swych zrębach nienaruszony - hegemonem pozostała KPCh, tyle że występująca jako partia władzy, a nie siewca rewolucji, w tym światowej ${ }^{25}$, jak przedtem.

Na tej podstawie na XIII Zjeździe KPCh we wrześniu 1987 r. zdefiniowano, jaki system obowiązuje w państwie. Nawiązując do koncepcji Deng Xiaopinga jeszcze z 1982 r., nazwano go „socjalizmem o chińskiej specyfice”26. Formalnie ten system istnieje w ChRL do dziś, tyle tylko, że jedna z najlepszych prac dotyczących chińskiej transformacji gospodarczej nosi tytuł Kapitalizm o chinskiej specyfice ${ }^{27}$. To dowodzi, że raz jeszcze skorzystano z własnej bogatej spuścizny cywilizacyjno-kulturowej, z dychotomii ying i yang, pierwiastków męskiego i żeńskiego, jasnego i ciemnego, aktywnego i biernego. Wbrew oczekiwaniom Zachodu, przekonanego, że „nie ma trzeciej drogi”, połączono socjalizm z kapitalizmem - i czasami doprawdy trudno rozróżnić, co jest czym. Jednakże dominacja KPCh i autokratyczne rządy wskazują, że rozluźnienie i swobody w gospodarce nie szły w parze z wolnościami politycznymi, a przynajmniej nie na taką skalę, jak spodziewano się na Zachodzie, gdzie utrwaliło się przekonanie, iż liberalizacja gospodarcza doprowadzi z czasem do politycznej.

Deng w obronie socjalizmu nie zawahał się wystapić po raz wtóry, gdy wiosną 1989 r., co wiemy już na pewno, osobiście wydał rozkaz siłowego stłumienia demonstracji na placu Tiananmen ${ }^{28}$. Ferment i masowe demonstracje utopiono we krwi kosztem własnego wizerunku na świecie, czego Deng się spodziewał, ale nie obawiał. Znacznie gorsze dla niego było to, że w wyniku tego politycznego przesilenia do władzy doszli konserwatyści, w istocie pragnący powrotu do maoistowskiej ortodoksji, na co w żaden sposób nie chciał się zgodzić. Kiedy więc 25 grudnia 1991 r. Michaił Gorbaczow był zmuszony zdjąć czerwona gwiazdę z kremlowskich baszt, a ZSRR odszedł do historycznych annałów, pragmatyczny Deng Xiaoping

${ }^{24}$ Deng Xiaoping, Chińska droga..., s. 106; krytyczna analiza zob. A.V. Pantsov, Levine, Deng Xiaoping..., s. 345-357.

${ }^{25}$ W tym także w ramach głośnej teorii trzech światów, w której na czele trzeciego rewolucyjnego świata miały stać Chiny. Co ciekawe i znaczące, zajęty reformami wewnętrznymi Deng nigdy oficjalnie tej teorii nie odrzucił - odeszła ona do lamusa w sposób naturalny. Szerzej o strategii Mao: K. Makowski, Świat wedlug Mao Zedonga - doktrynalne podstawy cbinskiej polityki zagranicznej (1949-1976), Toruń 2005. O teorii trzech światów traktuje rozdział V (s. 150-185). Tam też, na następnych stronach, o dalszych losach tej teorii, ale tylko do roku 1979.

26 You Zhongguo te se de shubuizhuyi. Dwie ciekawe, krytyczne oceny funkcjonowania tego unikatowego systemu politycznego: D. Shambaugh, China's Communist Party. Atropby and Adaptation, Berkeley-Los Angeles 2008; R. McGregor, Partia. Sekretny swiat komunistycznych władóow Chin, Kraków 2013.

27 Yasheng Huang, Capitalism With Chinese Characteristics, Entrepreneurship and the State, Cambridge-New York 2008.

28 The Tiananmen Papers. The Chinese Leadership's Decision to Use Force Against Their Own People: In Their Own Words, oprac. Zhang Liang, New York 2001, s. 354-362. 
przypomniał sobie mantrę, jakiej uczono chińskich komunistów, a nawet dzieci w szkołach w latach 50 . XX stulecia, gdy oba państwa na krótko połączyły się w sojuszu: „Związek Radziecki dziś to nasze jutro”29. Wypływa stąd prosty wniosek: członków KPCh też czeka ten los, jeśli nie wprowadzą kolejnych głębokich zmian.

\section{Taoguang yanghui, czyli low profile}

Ponieważ blok wschodni, a potem ZSRR rozpadły się, zaś ortodoksyjny komunizm utrzymał się jedynie w KRLD i na Kubie (Wietnam i Laos poszły drogą chińskich reform), trzeźwo kalkulujący Deng doszedł do wniosku, że nie ma innego wyjścia, jak włączenie Chin do globalizacji i gospodarki światowej, a więc kapitalistycznej, bo innej w gruncie rzeczy nie było. W tym celu, niczym dawni cesarze, udał się w pielgrzymkę na południe kraju (nan xun). Tam, na terenie dawnych stref gospodarczych, z których funkcjonowania był bardzo zadowolony, na przełomie stycznia i lutego 1992 r. ogłosił swój polityczny testament (później, cierpiąc na starcze choroby, nie był już aktywny aż do śmierci) ${ }^{30}$. Nakazał swoim następcom, by nie tyle szukali rozwiązań na Zachodzie, forsującym wówczas neoliberalny konsensus z Waszyngtonu ${ }^{31}$, ile poszukiwali doświadczeń i natchnienia wśród - chińskich z natury ${ }^{32}$ - „azjatyckich tygrysów" gospodarczych, a przede wszystkim powielali rozwiązania stosowane w Singapurze ${ }^{33}$, gdzie działa w istocie jedna partia, istnieje słaba opozycja, za to wyróżniaja go nowoczesność i szybko rosnące bogactwo ${ }^{34}$. Tym samym Chiny włączyły się w model określany przez specjalistów jako prorozwojowy ${ }^{35}$, a zarazem

29 R. Terrill, What Does China Want?, "The Washington Quarterly" Autumn 2005, http:/ /archive. wilsonquarterly.com/essays/what-does-china-want (dostęp: 30.12.2016).

30 Selected Works of Deng Xiaoping, vol. 3, (1982-1992), Beijing 1994, s. 358-370; krytyczna ocena: E.F. Vogel, Deng Xiaoping..., s. 664-676.

31 Washington Consensus zakładał m.in. deregulację i liberalizację rynków, produkcji oraz masową prywatyzację: E. Haliżak, Ideowe problemy globalnego tadu liberalnego w gospodarce swiatowej - rola $i$ znaczenie Washington Consensus [w:] Globalizacja a stosunki miedzynnarodowe, red. E. Haliżak, R. Kuźniar, J. Symonides, Bydgoszcz-Warszawa 2004, s. 12-30.

32 Poza Korea, która zawsze była mocno konfucjańska. Wnikliwe studium: Sor-Hoon Tan, Confucian Democracy. A Deweyan Reconstruction, New York 2004.

33 Co znamienne, Deng zaprzyjánił się, z wzajemnością, z założycielem tego miasta-państwa, Lee Kuan-yew, przekonanym antykomunistą. O stosunku tego ostatniego do chińskiego wizjonera zob. W. Ali, R.D. Blackwill, A. Graham, Chiny, Stany Zjednoczone i swiat w oczach wielkiego mistrza Lee Kuan Yewa, Warszawa 2013, s. 141.

${ }^{34} \mathrm{O}$ modelu singapurskim zob. B. Pieliński, Mięšy Japoniq a Singapurem. Rozwój polityki społecznej w Azji Wschodniej, Warszawa 2013.

35 Pierwszy użył go znany ekspert amerykański ds. Azji Wschodniej Chalmers Johnson w klasycznej pracy na temat japońskiego cudu gospodarczego i roli w nim potężnego Ministerstwa Handlu i Przemysłu - MITI. Szerzej na ten temat: A. Bolesta, China ..., s. 7-53. 
zaprzestały prowadzonych dotąd od grudnia 1978 r. reform socjalizmu i włączyły się do światowego obrotu gospodarczego.

Dopiero po 1992 r. Państwo Środka jeszcze bardziej otworzyło się na świat, w zamian zaś zaczęto inwestować na wielką skalę obce kapitały, już nie tylko te z kies hua qiao. W tym celu ChRL zintensyfikowała starania o przyjęcie do GATT (po 1995 r. Światowej Organizacji Handlu - WTO), po raz pierwszy w dziejach chińskiej cywilizacji godząc się na pewne rozwiązania prawne wypracowane poza Państwem Środka (ostatecznie uwieńczono je przyjęciem Chin do WTO w grudniu 2001 r. $)^{36}$. Tym samym zakończyły się prowadzone dotąd reformy realnego socjalizmu, a rozpoczęła się prawdziwa transformacja gospodarcza, z Chinami jako integralną częścią zglobalizowanej gospodarki ${ }^{37}$.

Mając na uwadze tak szerokie wyjście na świat, wizjonerski Deng Xiaoping podyktował swoim następcom swój faktyczny polityczny testament, czyli tzw. konstytucję (lub strategię) 28 chińskich znaków. Sięgając raz jeszcze do wielkiej tradycji i spuścizny kulturowej, w tym zakorzenionych w niej tzw. chengyu, a więc przysłów, przypowieści i filozoficznych formuł, często złożonych z czterech, rzadziej większej liczby chińskich znaków ${ }^{38}$, stworzył własne maksymy i zwrócił się do swoich następców z następującymi zaleceniami czy wręcz przykazaniami:

- Lengïng guancha - uważnie obserwować i chłodno analizować sytuację;

- Yousuo zuowei - starać się wnosić swój wkład;

- Wen zһu zһenjiao - trzymać grunt pod nogami, bronić własnych interesów;

- Chenzhuo yingfu - podchodzić do zmian spokojnie i z pewnością siebie;

- Shanyu shouz̧һuo - zachować ostrożność, nie wywyższać się;

- Juebu dang tou - nie starać się być liderem;

- Taoguang yangbui - ukrywać własne możliwości i zamiary ${ }^{39}$.

Te strategiczne założenia były objęte w ChRL konsensusem i wprowadzane w życie co najmniej do końca pierwszej dekady XXI wieku. Chiny prezentowały się na zewnątrz jako państwo skromne, na dorobku, a dopiero z czasem zaczęły się prezentować jako „największe państwo rozwijające się na globie” (co powtarzaja,

36 China in WTO: Past, Present and Future, https://www.wto.org/english/thewto_e/acc_e/s7lu_e.pdf (dostęp: 2.01.2017).

${ }^{37}$ Szerzej: Li Kang, Globalization and Cultural Trends in China, Honolulu 2004. Aspekty ekonomiczne: Yasheng Huang, Selling China. Foreign Direct Investment During the Reform Era, CambridgeNew York 2003.

38 Dobre polskie opracowanie: J. Plebaniak, Starożytna madrość chinskea w sentencjach, Warszawa 2010. Faktycznie użyte przez Denga było tylko jedno chengyu, taoguang yanghui, wywodzące się jeszcze ze starożytnej tradycji buddyjskiej. Resztę Deng najwyraźniej stworzył sam, chociaż dokładnie w tym duchu.

39 J. Rowiński, Ewolucja polityki..., s. 245. Rozszerzenie tych pojęć i kryjących się za nimi wieloznaczności: D. Mierzejewski, Między pragmatyzmem..., s. 140, 141; por. K. Mahbubani, The New Asian Hemisphere. The Irresistible Shift of Global Power to the East, New York 2008, s. 224. 
coraz rzadziej, do dziś). Bez rozgłosu kumulowały i zbierały swe siły, a zarazem starannie kryły swe możliwości, intencje i zamiary. Zatem nie dziwi, że kiedy stało się jasne, iż ta strategia obowiazuje i jest skrupulatnie wprowadzana w życie, nazwano ją właśnie taoguang yanghui.

Chiny najwyraźniej czekały na lepsze czasy dla siebie, a równocześnie szybko się modernizowały i reformowały, nadal jednak odrzucając wszelkie modele i sugestie zachodnie. Dlatego wiosną 2004 r. wykładający na chińskiej uczelni Amerykanin Joshua C. Ramo sformułował tezę, że Państwo Środka w swoich reformach stosuje zasady „konsensusu z Pekinu” (Beijing gongshi - Beijing Consensus ${ }^{40}$. Autor nie do końca wyjaśnił, na czym te zasady polegaja lub miałyby polegać, jego tekst w wielu fragmentach był i pozostaje dość niejasny, za to przesłanie z niego płynące było wyjątkowo jasne: „konsensus z Pekinu” jest niczym innym, jak prostym zaprzeczeniem neoliberalnych zasad „konsensusu waszyngtońskiego”. Na tej podstawie pojawily się na Zachodzie tezy, że Pekin buduje „model nieliberalny”, oparty na osmozie rynku i państwa, który może okazać się bardziej skuteczny od tego obowiązującego na Zachodzie ${ }^{41}$.

Nic dziwnego, że Chińczycy trzymający się zaleceń strategii 28 znaków i formuły taoguang yanghui nie zastosowali u siebie neoliberalizmu, zwanego nierzadko „rynkowym fundamentalizmem” ${ }^{42}$. Nie chcieli też stosować pojęcia „konsensusu z Pekinu" - po pierwsze dlatego, że wystawiałoby to ich na konfrontację z USA i Zachodem, której nie chcieli, a po drugie dlatego, że nie była ich własna. Kiedy na początku 2010 r., reagując na wielki kryzys na światowych (zachodnich) rynkach z 2008 r., rozpoczęli wielką, trwającą do dziś debatę nad następną fazą reform, a nawet nowym modelem rozwojowym kraju (co już wychodzi poza zasięg niniejszych rozważań), wtedy powołali się nie na „konsensus z Pekinu”, lecz na formułę Zhongguo moshi, a więc „chińskiego modelu rozwojowego”, znowu własnego i niepowtarzalnego ${ }^{43}$.

Szerokie otwarcie na świat własnego ogromnego rynku przyniosło z sobą wielkie sukcesy w ślad za starannie wprowadzaną w życie strategią łączenia się $\mathrm{z}$ globalnymi rynkami i wewnętrznej liberalizacji. Chiny tylko w okresie 1992-1994, gdy wreszcie naprawdę otworzyły się na światowe rynki i globalizację, przyjęły ponad

\footnotetext{
40 J. Ramo, The Beijing Consensus, The Foreign Policy Centre, London 2004, dostępny online: http:/ / fpc.org.uk/fsblob/244.pdf (dostęp: 30.12.2016).

41 S. Halper, The Beijing Consensus. How China's Authoritarian Model Will Dominate The Twenty-First Century, New York 2010, s. 121, 126.

42 Zhongguo Moshim yu "Beijing Gongshi". Zhaocheng "Huachengdun Gongshi [Chiński model rozwojowy a "Konsensus z Pekinu”. Wychodząc poza "konsensus z Waszyngtonu”], red. Yu Keping, Huang Ping at al., Bejing 2006, zob. zwłaszcza podsumowanie debaty na ten temat (s. 409-434).

43 Kluczowa praca na ten temat: Zheng Yongnian, Zhongguo Moshi. Jingyan yu tiaoz̧han [Chiński model rozwojowy. Doświadczenia i wyzwania], Beijing 2016; omówienie debaty: B. Góralczyk, W poszukiwaniu chinskiego modelu rožwojowego, „Sprawy Międzynarodowe” 2016, nr 1, s. 40-61.
} 
11 mld USD nowych inwestycji - więcej niż w całej pierwszej dekadzie reform ${ }^{44}$. Natomiast już w końcówce lat 90. minionego stulecia zamieniły się w światowa taśmę produkcyjna, a równocześnie - na wzór innych państw prorozwojowych, a przede wszystkim Korei Południowej i Japonii - zaczęły budować własne marki i konglomeraty państwowo-prywatne, które dzisiaj już są dobrze znane: Lenovo, Huawei, Heier, ZTE, TCL, Xiaomi, Tencent itd. ${ }^{45}$

Pierwsza dekada XXI wieku okazała się dla Chin wielkim pasmem sukcesów. Kraj, który przed ponad dwiema dekadami zaczął się reformować i wychodzić z izolacji, autarkii i głębokiej biedy, w październiku 2006 r. zebrał pierwszy bilion dolarów rezerw walutowych, choć u progu reform nie miał ich wcale (o ogromnym przyspieszeniu świadczy fakt, że na koniec 2014 r. miał już około 4 biliony rezerw ${ }^{46}$. W obecne stulecie ChRL wkroczyła jeszcze jako szósta gospodarka świata, a w roku 2010 była już druga, wyprzedzając Japonię, co miało dla niej ogromne symboliczne i psychologiczne znaczenie. Rok wcześniej Chiny wyprzedziły Niemcy i stały się największym państwem eksportującym na globie, a w 2014 r. dodały do tego tytuł największego państwa handlującego. W tym też roku dokonały zwrotu iście kopernikańskiego, bowiem inwestycje do nich przychodzące, po $1992 \mathrm{r}$. zazwyczaj duże, po raz pierwszy były mniejsze od inwestycji z Chin wychodzących ${ }^{47}$. Importer kapitału zamienił się w jego eksportera. Były to zmiany tym bardziej zdumiewające, jeśli uwzględni się - wspominany na wstępie tego tekstu - punkt startu. W takim kontekście pojawiły się tezy, że to Chiny, a nie USA, jak się wcześniej spodziewano i oczekiwano, stały się największym beneficjentem globalizacji. Strategia skromności i spokojnego zbierania sił bardzo się opłaciła, jak również okazała się niezwykle skuteczna.

44 Zhu Rongji meets the press, Beijing 2012, s. 22. Działania te były prowadzone pod dyktando bodaj najśmielszego reformatora całego okresu reform i transformacji, wyznaczonego jeszcze przez Deng Xiaopinga - najpierw wicepremiera odpowiedzialnego za gospodarkę, a w latach 1998-2003 premiera Zhu Rongji. Zhu przeszedł do historii powiedzeniem: „Potrzeba mi 100 trumien - 99 dla niekompetentnych i skorumpowanych biznesmenów i urzędników i 1 dla mnie”. Był on jednym z wielkich zwolenników budowy „socjalistycznej gospodarki rynkowej”, gospodarczym liberałem, ale też zwolennikiem interwencjonizmu państwowego, z którego sam chętnie korzystał. Zhu osobiście odpowiadał też za negocjacje nad przyjęciem do WTO.

${ }^{45} \mathrm{O}$ tym fenomenie wielkich chińskich firm, przede wszystkim w dziedzinie wysokich technologii, na światowych rynkach: E. Tse, China Disruptors. How Alibaba, Xiaomi, Tencent and Other Companies are Changing the Rules of Business, New York-London 2015. Zob. recenzja: B. Góralczyk, Konkurencja jedzie po bandzie, „Obserwator Finansowy”, 23.01.2016: https://www.obserwatorfinansowy.pl/tematyka/makroekonomia/konkurencja-jadaca-po-bandzie/ (dostęp: 2.01.2017).

$46 \mathrm{http}: / /$ www.tradingeconomics.com/china/foreign-exchange-reserves (dostęp: 2.01.2017).

47 Dobre podsumowania sukcesów epoki reform można znaleźć w pracach chyba najgłośniejszego chińskiego stratega gospodarczego: Hu Angang, China in 2020. A New Type of Superpower, Washington 2011, s. 1-12; Hu Angang, Zhongguo Xin Zhanlüe [Nowa strategia Chin], Beijing 2015, s. $10-15$. 


\section{Asertywność piątej generacji przywódców}

Kryzys 2008 r. uświadomił chińskim przywódcom, że sytuacja międzynarodowa gruntownie się zmieniła. Dotychczasowy hegemon, USA, stracił swój status jedynowładcy, przynajmniej w sensie gospodarczym i finansowym. Świat ponownie stawał się wielobiegunowy, z szybko rosnącą rolą tzw. wschodzących rynków (czego dowodami są zamiana G-7/G-8 w G-20 oraz powołanie grupy BRIC, potem BRICS).

Owszem, Chińczycy starali się zapewniać świat, że choć rosną tak szybo, w tempie dwucyfrowym rocznie (za okres 1978-2012 odnotowały przeciętny roczny wzrost w wysokości $9,8 \%{ }^{48}$, co jest bezprecedensowym sukcesem, na dodatek odniesionym w najludniejszym państwie świata), to maja pokojowe intencje i zamiary. Najlepszym tego dowodem są dwie „Białe Księgi” chińskiego rządu na ten temat z roku $2005^{49}$ i $2011^{50}$. Nawiązywano w nich do tezy sformułowanej przez znanego eksperta Zheng Bijiana, mówiącej o „pokojowym wzroście” (beping jueqi - peaceful rise $)^{51}$. Termin ten następnie, aby wzbudzać kontrowersji co do szybkiego wzrostu własnego znaczenia, zamieniono na ,pokojowy rozwój” (beping fazan - peaceful development). W obu tych dokumentach nawiazywano do znanych ,pięciu zasad pokojowego współistnienia", ale zarazem podkreślano, że Chiny sprzeciwiają się wszelkiej hegemonii na scenie międzynarodowej (w podtekście: USA) i dążą do (od)budowy porządku wielobiegunowego. Wydanie w odstępie niespełna 6 lat dwóch tak ważnych dokumentów rządowych wskazywało, że władze w Pekinie doskonale zdają sobie sprawę z tego, iż tak szybki wzrost potęgi i znaczenia chińskiego kolosa musi budzić rosnące zainteresowanie, a czasami też niepokoje na arenie światowej.

Dlatego też, trzymając się nadal formuł strategii taoguang yanghui, Chiny początkowo nie chciały pozytywnie odpowiedzieć na pojawiające się apele byłego szefa Banku Światowego Roberta Zoellicka, by stały się „odpowiedzialnym współudziałowcem" (responsible stakeholder) na scenie światowej ${ }^{52}$. Nie przystały też na propozycję nowej administracji Baracka Obamy, zaproponowanej Pekinowi przez ekonomistę Freda Bergstena i przywiezionej tam osobiście przez Zbigniewa Brzezińskiego, by utworzyć na świecie swego rodzaju tandem pod nazwą $\mathrm{G}-2^{53}$.

48 http://www.tradingeconomics.com/china/gdp-growth-annual; http://data.worldbank.org/ indicator/NY.GDP.MKTP.KD.ZG (dostęp: 30.12.2016).

49 Pełny tekst: http://in.chineseembassy.org/eng/zt/peaceful/t855717.htm (dostęp: 2.01.2017).

50 Pełny tekst: http://news.xinhuanet.com/english2010/china/2011-09/06/c_131102329_2. htm (dostęp: 2.01.2017).

51 Zheng Bijian, China's Peaceful Rise: Speeches of Zheng Bijian 1997-2005, Brooking Institution, Washington 2005.

52 Pełny tekst: R. Zoellick, Wither China? From Membership to Responsibility?, New York, 21.09.2005, https://2001-2009.state.gov/s/d/former/zoellick/rem/53682.htm (dostęp: 2.01.2017).

53 Świetna analiza Henry C.K. Liu: http://henryckliu.com/public_html/page186.html (dostęp: 2.01.2017). 
Sygnały płynące $\mathrm{z}$ wewnattrz (w tym problemy $\mathrm{z}$ dotychczasową ekspansją inwestycyjna), a nade wszystko z zewnątrz (gdzie podważona została ekonomiczna dominacja Zachodu) wymusiły jednak istotne zmiany. Tak zwana piąta generacja przywódców z Xi Jinpingiem jako primus inter pares, która - na podstawie wypracowanych również przez Deng Xiaopinga zaleceń nawiązujących do konfucjańskich formuł merytokracji $1^{54}$ - doszła do władzy w Pekinie na przełomie lat 2012/13, najwyraźniej postanowiła dostosować się do zmieniających się okoliczności. Zdecydowano się zerwać $z$ dotychczasową strategia skromności i ukrywania swych sił na rzecz nowej asertywności i bardziej zdecydowanej pewności siebie, niż zalecał Deng (formuła: chenz̧huo yingfu). Rozpoczęła się implementacja zupełnie nowej strategii - jeszcze większego i głębszego wyjścia na zewnątrz. Chiny wreszcie postanowiły brać odpowiedzialność za sprawy światowe, nie tylko własne. Robią to jednak ostrożnie i wybiórczo, np. włączając się aktywnie w misje pokojowe ONZ czy w walkę ze zmianami klimatycznymi na globie.

Nowa ekipa piątej generacji po raz pierwszy pokazała się w całości w symboliczny sposób: ubrana w tzw. mundurki Mao (w rzeczywistości modę tę narzucił jeszcze Sun Yat-sen) pojawiła się w Chińskim Muzeum Narodowym przy placu Tiananmen, gdzie - co znamienne - prezentowano wystawę fotograficzną Droga do odrodzenia, przestawiającą skutki wspominanych już tutaj „stu lat narodowego poniżenia". Przesłanie z niej płynące było jasne i oczywiste: Chiny były słabe i zdominowane przez innych, a teraz mają być silne i emanujące potęgą na świat. To tam 29 listopada $2012 \mathrm{r}$. Xi Jinping wygłosił pierwsze po XVIII zjeździe partii publiczne wystąpienie ${ }^{55}$. Podporządkował je jednemu hasłu: państwo wkracza w nową epokę spod znaku Zhongguo meng - chińskiego snu/marzenia, które dodatkowych znaczeń nabiera w tłumaczeniu na angielski: Chinese Dream. Podtekst jest czytelny i jednoznaczny: dotychczas mieliśmy do czynienia z epoką amerykańską - American Dream, teraz nadchodzi era Chin...

54 „Pierwsza generacja” to założyciele KPCh i ChRL. Strategię dopracowano dopiero w latach 90., po upadku ZSRR. Zgodnie z nią na czele państwa znajduje się przewodniczący ChRL, zwany na Zachodzie zwyczajowo „prezydentem” (głowa państwa), pełniący równocześnie funkcję szefa partii (stąd wchodzenie na przełomie lat, bo szefa partii wybiera w listopadzie zjazd KPCh, a przewodniczącego ChRL obradujący corocznie w marcu parlament) i głównodowodzącego armią. Obok niego główną funkcję wykonawczą pełni premier, dlatego często wymienia się na czele danej generacji tandem, dziś Xi Jinping - Li Keqiang, a wcześniej Hu Jintao - Wen Jiabao czy Jiang Zemin - Zhu Rongji. Pełnię władzy w kraju sprawuje Stały Komitet Biura Politycznego KC KPCh (dziś siedmioosobowy), swego rodzaju „kolektywny cesarz”. Można w nim zasiadać maksimum przez dwie pięcioletnie kadencje, a warunkiem jest wylegitymowanie się poprzednio zarządzaniem prowincją czy dużym miastem i nie można przekroczyć wieku 68 lat. Dba się również o to, by każda następna generacja przywódców była lepiej wykształcona - premier Li Keqiang płynnie mówi po angielsku, jest doktorem zarządzania i prawa.

55 Xi Jinping, The Governance of China, Beijing 2014, s. 37. Istnieje polska wersja tego tomu, zatytułowana Innowacyjne Chiny, przeł. S. Szafarz, Warszawa 2015, ale niestety tłumaczenie nie jest najlepsze. 
Co znaczące, najwyższy chiński przywódca nawiązał tym samym, choć nie powołując się otwarcie na nią, do wydanej na początku 2010 r. książki pułkownika chińskiej armii Liu Mingfu pod tym samym tytułem, która od tej pory znalazła się oczywiście we wszystkich księgarniach, w różnych wydaniach i edycjach. Co więcej, przez ponad rok wszystkie chińskie autorytety i gwiazdy - filmu, sportu, mediów, życia publicznego - wypowiadały się w państwowej telewizji w przerwach zamiast reklam, każda na swój sposób dowodząc, co rozumie przez pojęcie „chińskiego marzenia", co osobiście dla niej ono znaczy. Dowodziło to jednego: pomysł już był, ale szukano właściwej dla niego treści.

Wydano też w tym czasie specjalny podręcznik dla szkół na ten temat ${ }^{56}$. Równocześnie trwała, jeszcze bardziej ożywiona niż przedtem, debata nad tezami Liu Mingfu, a te były jednoznaczne w swej wymowie: „Chińska gospodarka będzie wiodąca na świecie i na tej podstawie Chiny staną się najsilniejszym państwem na globie (...) wyprzedzimy Zachód. Kiedy nasz naród będzie gotów, Chiny staną się mocne, bez wattpienia wyprzedzimy ich" ${ }^{57}$.

Jak widać, była to już zupełnie nowa retoryka i podejście całkiem odmienne od dotychczasowej strategii trzymania się w cieniu. Teraz Chiny, coraz pewniejsze swej siły, zaczęły zdecydowanie wkraczać na scenę światową. Oczywiście Xi Jinping tak ostrych tez jak Liu Mingfu i wielu wspierających go chińskich autorów nie stawiał. Ci ostatni, podobnie jak pułkownik chińskiej armii, odnosili się przede wszystkim do USA, które stanowi dla nich główny punkt odniesienia i najważniejsze wyzwanie. Od tej pory byli oni i pozostają zgodni co do tego, że Chiny wkrótce przegonia Stany Zjednoczone jako mocarstwo gospodarcze i na tej podstawie snuja własne koncepcje i wizje, wychodząc z coraz śmielszymi tezami.

Znany ekspert specjalizujący się w strategii Chin, Ye Zicheng kładzie nacisk na pokojowe zjednoczenie z Tajwanem jako warunek sine qua non nadchodzącej chińskiej mocarstwowości i pisze: „Chiny będą mogły stać się wielkim mocarstwem w dosłownym znaczeniu tego wyrażenia dopiero wówczas, gdy zakończą proces unifikacji”"58. Jego zdaniem w ramach nowych koncepcji i strategii „piątej generacji

56 Zhongguo Meng xuexi duben [Lektury szkoleniowe nt. „chińskiego marzenia”, red. Wang Yinghai, Beijing 2013. Już na wstępie, powołując się na starożytnych chińskich myślicieli, dowodzi się w nim, że Chiny „są skazane do statusu państwa numer jeden” na świecie (s. 21). Takie tezy wkłada się do głów wszystkim chińskim uczniom.

57 Liu Mingfu, Zhongguo meng. Hou Meiguo shidai de daguo siwei yu žhanlüe dingwei, Beijing 2010. Pojawiła się też, nie do końca zbieżna z chińskim oryginałem, amerykańska wersja tego tomu: The China Dream. Great Power Thinking and Great Power Posture in the Post-American Era, New York 2015. Cytaty z niej, s. 1, 2. Jego zdaniem, jak zapisano w wersji chińskiej (s. 15, 16), Deng Xiaoping nakreślił też swoim następcom „strategię trzech kroków”: pierwszy z nich to zapewnienie społeczeństwu wiktu i opierunku, drugi to budowa „społeczeństwa umiarkowanego dobrobytu”, a trzeci, do osiągnięcia za 50 lat, to „wielki renesans chińskiego narodu”.

58 Ye Zicheng, Inside China's Grand Strategy. The Perspective from the People's Republic, Lexington 2011, s. 223. 
przywódców" Chiny przyjmą na siebie większą odpowiedzialność za sprawy światowe, przestaną być tym samym biernym obserwatorem i staną się aktywnym graczem, a ich geostrategia będzie polegała na tym, by „stabilizować Zachód, opierać się na Północy [tzn. współpracy z Rosją - B.G.] i współzawodniczyć na południowym wschodzie"59, czyli na Morzu Południowochińskim.

Wybitny politolog, znany też ze swych mocno nacjonalistycznych poglądów Yan Xuetong proponuje inną strategię i zaleca chińskim przywódcom sięganie do skarbnicy starożytnej chińskiej mądrości. On też otwarcie przyznaje, że poprzednia strategia Deng Xiaopinga spokojnego budowania mocy i umiaru w nowych uwarunkowaniach, gdy Chiny są już silniejsze, jest przestarzała. Toteż postuluje, by władze w Pekinie wyszły poza dotychczas praktykowane rozważania ograniczone jedynie do sfery gospodarczej. Jego zdaniem odradzające się Chiny jako nowa potęga mają całemu światu wiele do zaproponowania, także w sztuce strategii czy rządzenia i nie jest w tej opinii odosobniony ${ }^{60}$. Autor ten nie ma wątpliwości, że Chiny „w XXI wieku z sukcesem lub porażką przejdą historyczny test na swej drodze do statusu supermocarstwa" ${ }^{61}$. Dlatego podpowiada, że rosnące w siłę Państwo Środka powinno nie tyle sięgać po hegemonię (ba), ile czerpać ze starożytnej koncepcji wang dao, a więc rządzenia poprzez przykład, narzucania innym własnych cywilizacyjnych wzorców ${ }^{62}$.

Do tego samego terminu wang dao jeszcze chętniej sięga, a zarazem wyostrza tezy Yan Xuetonga inny znany badacz, celebryta medialny, a kiedyś osobisty tłumacz Deng Xiaopinga, Zhang Weiwei. Twierdzi on wprost, że Chiny są niczym innym jak „państwem cywilizacja”” (wenmingxing guojia - civilizational state), czemu poświęcił popularną w ChRL trylogię̧ ${ }^{63}$. Chętnie eksponuje on przywary zachodniej liberalnej demokracji, wskazując na związane z nią populizm czy krótkoterminowość w myśleniu, ale równocześnie nie pozostawia żadnych wątpliwości co do tego, że Chiny mają własny model, wynikający z ich bogatej tradycji i cywilizacji, a opierający się na „czterech cechach specyficznych” (si dute $)^{64}$. W jego opinii Pań-

59 Ibidem, s. 202, 257.

60 Yan Xuetong, Ancient Chinese Thought, Modern Chinese Power, Princeton-Oxford 2011, s. 217.

${ }^{61}$ Ibidem, s. 203.

${ }^{62}$ Ibidem, s. 71.

${ }^{63}$ Chodzi o tomy: Zhongguo zhenhan [Chiński wstrząs], Zhongguo chudong [Chińskie poruszenie] i Zhongguo ₹haoyue [Chiński horyzont], wydane przez to samo wydawnictwo Shiji Chuban Jituan w Szanghaju w latach 2011, 2012 i 2014. Na ich podstawie autor sam przetłumaczył na język angielski $\mathrm{i}$ wydał dwa tomy: The China Wave. Rise of Civilizational State oraz The China Horizon. Glory and Dream of a Civilizational State, wydane przez wydawnictwo World Century (New York 2011 i 2016). Całość należy uznać za jeden wielki pean na rzecz Chin potencjalnie wielkich, nie tylko doganiających Zachód, ale nawet prześcigających go - zarówno w wymiarze gospodarczym i finansowym, jak i cywilizacyjno-kulturowym, a spodziewane i zapowiadane jest także chińskie wyzwanie technologiczne. Jest to kolejny ważny temat.

${ }^{64}$ Zhang Weiwei, The China Wave..., s. 63. 
stwo Środka wyróżnia odmienny język, system polityczny, społeczeństwo (w domyśle: konfucjańskie, a więc szanujące hierarchię i wartości zbiorowe) oraz system gospodarczy, łączący rynek z interwencjonizmem państwowym ${ }^{65}$. Mając na uwadze te założenia, Chiny jako państwo cywilizacja, powinny nadal kroczyć własną drogą i nie tyle ogląać się na Zachód, ile jeszcze szerzej i głębiej sięgać do bogatej skarbnicy własnych wartości.

Idący w ślad za takimi koncepcjami znany ekspert od spraw amerykańskich, Jin Canrong też nie pozostawia wątpliwości co do wzrostu znaczenia Państwa Środka na arenie międzynarodowej, a przy tym zauważa: „Dzisiejszy marsz Chin ku centrum światowej areny to nieunikniona rzeczywistość (...). Fakt, że Chiny sa pchane ku centrum światowych wydarzeń, jest wynikiem raczej obiektywnej sytuacji, a nie naszego subiektywnego projektu" ${ }^{66}$. Rozumiejąc jednak bardziej niż inni, że szybki wzrost znaczenia Chin na arenie międzynarodowej budzi na świecie mieszane uczucia, sięga po argument często przytaczany przez chińskich ekspertów: „Prawdziwym zagrożeniem dla świata byłby nie rozwój chińskiej gospodarki, lecz jej upadek" Innymi słowy: nie mieszajcie się! Chiny mają rozwijać się same, chociaż oczywiście pozostając otwarte na świat.

Nic dziwnego, że w takiej intelektualnej atmosferze, gdy najwybitniejsi eksperci w kraju podpowiadali przywódcom, iż Chiny są na drodze ku przywróceniu im dawnego blasku i świetności, Xi Jinping zaczął wyznaczać nowe cele i zdania, a także harmonogramy dotyczace ich osiagnięcia ${ }^{68}$. Początkowo nie było do końca jasne ani czym ma być wypełnione jego „chińskie marzenie” (poza tym, że większą asertywnością i pewnością siebie, płynąca z rosnącej siły gospodarczej), ani kiedy miałoby zostać zrealizowane. Owszem, już na wystawie poświęconej „stu latom narodowego poniżenia" Xi wskazał datę 1 lipca 2021 r., a więc stulecie utworzenia KPCh, ale do końca nie określono, co do tej pory ma zostać osiagnięte.

Sprawę powoli i stopniowo wyjaśnił i sprecyzował on sam. Nawiązując do swego referatu podczas XVIII Zjazdu KPCh, Xi Jinping postawił przed partią i państwem „dwa cele na stulecie” (liangge yi bai nian) ${ }^{69}$. Pierwszy z nich miał charakter czysto wewnętrzny i nadrzędny, jest traktowany jako zadanie do zrealizowania w pierwszej kolejności. Chodzi o to, by zbudować w Chinach „społeczeństwo umiarkowanego dobrobytu" (xiaokang shebui), czyli klasę średnią, bez której nie będzie możliwa

${ }^{65}$ Zhang Weiwei, Zhongguo zhenhan ..., s. 64.

${ }^{66}$ Jin Canrong, Odpowiedzialność wielkiego mocarstwa. Chinska perspektywa, przel. M. Ciecierski, Toruń 2012, s. 7, 8.

${ }^{67}$ Jin Canrong, Prayszłośc Chin, przeł. J. Kułaczkowski, Torun 2013, s. 15.

68 Szersze jej omówienia: na scenie wewnętrznej, B. Góralczyk, W poszukiwwaniu chińskiego modelu..., oraz na arenie zewnętrznej: idem, Ewolucja międzynarodowej strategii Chin (1985-2015) [w:] Region Azji i Pacyfiku w latach 1985-2015, red. A. Jarczewska, J. Zajączkowski, Warszawa 2016, s. 53-73.

${ }^{69} \mathrm{Xi}$ Jinping, The Governance..., s. 60. 
zmiana modelu rozwojowego z dotychczas ekstensywnego, opartego na wysokim wzroście i eksporcie, na model zrównoważonego rozwoju, opartego na silnym rynku wewnętrznym i zwiększonej konsumpcji. W tym celu Xi nawiązał do koncepcji po raz pierwszy wyartykułowanej przez jego poprzednika, Jiang Zemina jeszcze w 2001 r. ${ }^{70}$ Modyfikując nieco założenia Jianga, postawił sobie za cel, by od 2012 do 2020 r. przeciętne dochody na głowę każdego mieszkańca ChRL wzrosły dwukrotnie $^{71}$ w wymiarze realnym, co ma zostać zrealizowane właśnie do 1 lipca $2021 \mathrm{r}$.

Większy kłopot był z drugim celem na stulecie ${ }^{72}$. Ostatecznie niepewność i spekulacje na ten temat przeciął ponownie sam Xi Jiping podczas niezmiernie ważnego wystapienia 29 listopada 2014 r. na specjalnej, zwołanej po kilkunastoletniej przerwie, konferencji gromadzącej osoby zajmujące się polityką zagraniczną i bezpieczeństwa w państwie ${ }^{73}$. Tu zarysowano nową strategię wewnętrzną i zewnętrzną państwa. Zgodnie z nią drugim celem na stulecie, po który ChRL ma sięgnąć do 1 października 2049 r., czyli na swoje stulecie, ma być promowane coraz głośniej od XVIII Zjazdu hasło „wielkiego renesansu narodu chińskiego" (Zhonghua minzu weida fuxing ${ }^{74}$. Ono z kolei - według słów Xi - ma oznaczać zbudowanie do tego czasu „nowoczesnego socjalistycznego społeczeństwa, dobrze prosperującego i silnego, a zarazem demokratycznego, kulturowo zaawansowanego i harmonijnego" "75. Wreszcie pułkownik Liu Mingfu i jemu podobni mieli jasność, kiedy chiński naród „będzie gotów”.

Natomiast, co znaczące, Xi Jinping połączył hasło mówiące o „renesansie” z „chińskim marzeniem”. Obecnie obowiązująca mantra brzmi: „wielki renesans narodu chińskiego to chińskie marzenie”. Jednak już teraz Xi Jinping i w ślad za nim

${ }^{70}$ Jiang Zemin Wenxuan [Dzieła wybrane....], t. 3, Beijing 2006, s. 528.

71 Jiang mówił o czterokrotnym wzroście w okresie 2002-2020, ale jego następcy z czwartej generacji przywódców postawili przed sobą inne cele, opowiadając się za budową „, harmonijnego społeczeństwa" (hexie shehui), też nawiązując w ten sposób do idei konfucjańskich.

72 Popularna chińska encyklopedia internetowa Baidu wiąże „chińskie marzenie” z koncepcją „wielkiego renesansu chińskiego narodu” na cztery sposoby, trzy pierwsze poświęca sprawom wewnętrznym, a dopiero czwartą rosnącym zadaniom na scenie międzynarodowej. http:/ / baike.baidu.com/item $/ \% \mathrm{E} 4 \% \mathrm{~B} 8 \% \mathrm{~A} 4 \% \mathrm{E} 4 \% \mathrm{~B} 8 \% \mathrm{AA} \% \mathrm{E} 4 \% \mathrm{~B} 8 \% 80 \% \mathrm{E} 7 \% 99 \% \mathrm{BE} \% \mathrm{E}-$ 5\%B9\%B4/4272808?fr=aladdin (dostęp: 30.12.2016).

${ }^{73}$ Pełny tekst: http://www.fmprc.gov.cn/mfa_eng/zxxx_662805/t1215680.shtml (dostęp: 2.01.2017). Krytyczna analiza: M.D. Swaine, Xi Jinping's Address to the Central Conference on Work Relating to Foreign Affairs: Assessing and Advancing Major: Power Diplomacy with Chinese Characteristics, https://www.hoover.org/sites/default/files/clm46ms.pdf (dostęp: 2.01.2017). Ocena: B. Góralczyk, Tygrysy na chińskiej drodze. Nowa strategia Państwa Środka, http://wiadomosci.wp.pl/kat,1027191,title,Tygrysy-na-chinskiej-drodze-Nowa-strategia-Panstwa-Srodka,wid,17313374,wiadomo sc.html (dostęp: 2.01.2017).

${ }^{74}$ Po raz pierwszy użył go Zhao Ziyang już w końcówce lat 80. Termin znacznie rozwinął Jiang Zemin, ale prawdziwego znaczenia nabrał on dopiero za czasów Xi Jinpinga. D. Mierzejewski, Między pragmatyzmem..., s. 180.

75 Xi Jinping, The Governance..., s. 38. 
inni chińscy przywódcy zmienili terminologię i w stosunku do USA oraz innych potęg zaczęli otwarcie mówić o „,relacjach między wielkimi państwami” (da guo waijiao guanxi $)^{76}$. Chiny już są bardziej asertywne i pewne siebie, niż były kilka lat wcześniej. Jasno definiują swoje zamiary i cele, także na arenie zewnętrznej. Nic dziwnego, że poprzednio obowiązująca strategia skromności i skrywania swych zamiarów taoguang yanghui odeszła do lamusa.

Nie będzie jednak spełnienia „,chińskiego marzenia” i żadnego „,renesansu”, jeśli naród chiński - Zhonghua minzu $u^{77}$ - będzie podzielony. Tylko Chiny zjednoczone i zwarte, skupione wokół celów i zadań stawianych przez obecnych mandarynów w Pekinie, będą wielką potęga. To jest stawka, o którą toczy się gra. Innymi słowy, pełny renesans będzie możliwy tylko i wyłącznie wówczas, gdy dojdzie do pokojowego zjednoczenia z Tajwanem (bo militarne czy siłowe groziłoby poważnymi konsekwencjami). Pod tym względem strategia Pekinu jest więcej niż oczywista, problemem pozostaje natomiast stosunek Tajpej i władz Republiki Chińskiej na Tajwanie do tego zagadnienia.

Trzeba przyznać, że w tzw. stosunkach przez Cieśninę (Tajwańską) w ostatnich latach doszło do zmian iście tektonicznych. W okresie 2008-2016, gdy u władzy na wyspie ponownie był Guomindang, najwyraźniej przekonany co do tego, że Chiny szybko wyrastaja na nowa potęgę, doszło pomiędzy oboma chińskimi podmiotami do bezprecedensowego zbliżenia. Dwa poprzednio całkowicie od siebie odizolowane organizmy podpisały w tym czasie ponad 20 porozumień dwustronnych, w tym kluczową Umowę ramową o współpracy gospodarczej (Economic Cooperation Framework Agreement - ECFA) ${ }^{78}$, w istocie prowadząca do połączeniu gospodarek obu stron. Kiedy jednak władze tajwańskie/Guomindangu chciały podpisać z Pekinem umowę uzupełniającą ECFA, wprowadzając jej zapisy do tak delikatnych dziedzin, jak usługi, prawa autorskie czy autonomia uczelni i mediów, w ramach wynegocjowanej już Umowy handlowej w dziedzinie usług przez Cieśninę (Cross-Strait Service Trade Agreement - CSSTA), tajwańska młodzież i tamtejsza inteligencja zbuntowały

${ }^{76} \mathrm{~W}$ popularnym materiale przeznaczonym dla odbiorcy chińskiego jako ich integralne części wymienia się: spełnienie „chińskiego marzenia”, dobrobyt gospodarczy, wzrost siły militarnej oraz wzrost znaczenia politycznego państwa na arenie międzynarodowej: http://fanwen.wenku1.com/article/17110753.html (dostęp: 2.01.2017).

77 To pojęcie, teraz w ChRL powszechnie używane, też wymaga wyjaśnienia. Pojawiło się w końcówce ostatniej dynastii Qing, mandżurskiej z rodowodu. Rozpowszechnił je Sun Yat-sen. Zgodnie z nim naród chiński składa się z pięciu integralnych części: narodowości Han - rodowitych Chińczyków, a także Mandżurów (dynastia Qing), Mongołów (dynastia Yuan), Tybetańczyków (bo byli przez wieki związani z Chinami religijnie i politycznie) oraz definiowanej zarówno etnicznie, jak i religijnie narodowości Hui, czyli muzułmanów, a nie tylko Ujgurów w regionie Xinjiang. Teraz promowany „renesans” ma więc dotyczyć wszystkich narodowości w Chinach (łącznie 56), a także wszystkich Chińczyków, gdziekolwiek są.

78 R. Tuszyński, Polityczny i ekonomiczny mymiar Economic Cooperation Framework. Agreement - jego znaczenie na drodže do zjednoczenia obu cześsi Chin, Toruń 2013. 
się. Doszło do pierwszych na taką skalę od utworzenia tego organizmu w 1949 r. masowych rozruchów, nazwanych „ruchem słonecznikowym” (taijanghua xueyun) które uniemożliwily jej podpisanie.

Chociaż ostatecznie doszło do pokojowego rozwiązania, to skutki tego bezprecedensowego wystapienia ludności były poważne. CSSTA do dziś nie podpisano i nie wprowadzono w życie. Natomiast podważone zaufanie do władz Guomindangu i prezydenta Ma Ying-jeou sprawiło, że w wyborach w styczniu 2016 r. stracili oni władzę, ponownie na rzecz największej siły opozycyjnej - Demokratycznej Partii Postępowej - DPP (w latach 2000-2008 prezydentem był jej reprezentant Chen Shui-bian). Przedstawiciele tej partii, podobnie jak desygnowana przez nia pani prezydent Tsai Ing-wen, nie są aż tak wielkimi zwolennikami szybkiego zbliżenia z Pekinem jak poprzednicy ${ }^{80}$. Ponownie jako jedna z podstawowych wróciła kwestia większej samodzielności, choć nie suwerenności, Tajwanu na arenie międzynarodowej.

Odchodząca administracja, reagując na sondaże opinii publicznej, które jednoznacznie wskazywały na ponowne zwycięstwo DPP (w grudniu 2014 r. władzę utracił reprezentujący Guomindang mer Tajpej, co było znamienne), zdobyła się na jeszcze jeden ważki, a zarazem wielce symboliczny (co w cywilizacji chińskiej zawsze ma duże znaczenie) gest - 8 listopada 2015 r. doszło do pierwszego od podziału z 1949 r. spotkania przywódców obu chińskich organizmów, tytułujących się „panami” Xi Jinpinga i Ma Ying-jeou ${ }^{81}$. Kilka minut uścisku dłoni przed kamerami mówiło więcej niż wydawane komunikaty, których zresztą przy tej okazji nie było. Jednoznacznie chodziło o to, by wywrzeć nacisk na następną administrację tajwańska, by nawet nie próbowała powracać do haseł Chen Shui-biana i szukania większej samodzielności na arenie międzynarodowej. Guomindang, chociaż tego wyraźnie nie mówi, zdaje się już podzielać stanowisko Pekinu, że zjednoczenie obu chińskich organizmów jest nieuniknione, a niepewne jest tylko to, kiedy i na jakich warunkach nastąpi. Dlatego też spróbowano wywrzeć nacisk, by DPP po dojściu do władzy nie próbowała podważyć tzw. konsensusu '92, na mocy którego istnieją tylko jedne Chiny, tyle że odmiennie rozumiane po obu stronach Cieśniny Tajwańskiej ${ }^{82}$.

Jak widać, sekwencja planowanych wydarzeń jest starannie nakreślona i raz jeszcze, podobnie jak na początku reform Deng Xiaopinga, rozpoczyna się od kluczowych zadań na scenie wewnętrznej. Konieczna stała się zmiana dotychczasowego modelu rozwojowego, bowiem kontynuacja poprzedniego niosła z sobą wiele poważnych zagrożeń (korupcja, uwłaszczenie nomenklatury spod znaku KPCh, roz-

\footnotetext{
79 Ocena: http://fpif.org/taiwans-sunflower-revolution-one-year-later/ (dostęp: 2.01.2017).

80 http://thediplomat.com/2016/01/tsai-ing-wen-hardly-beijings-worst-nightmare/ (dostęp: 2.01.2017).

81 http:/ / www.wsj.com/articles/china-s-xi-jinping-and-taiwan-s-ma-ying-jeou-meet-insingapore-1446880724 (dostęp: 30.12.2016).

82 http://thediplomat.com/2016/08/tsais-refusal-to-affirm-the-1992-consensus-spellstrouble-for-taiwan/ (dostęp: 2.01.2017).
} 
warstwienie społeczne, zniszczenie środowiska naturalnego itp.), a tej zgodnie z założeniami nie da się dokonać bez wzmocnienia wewnętrznego rynku i zbudowania klasy średniej (już szacowanej na ponad $300 \mathrm{mln}$ osób) ${ }^{83}$. Dopiero gdy Chiny lądowe się wzmocnia, przyjdzie czas na „renesans”, rozumiany przede wszystkim - choć nie tylko - jako pokojowe zjednoczenie z Tajwanem, tyle że najprawdopodobniej na innej zasadzie niż maksyma ,jeden kraj, dwa systemy”, na mocy której przyłączono do macierzy Hongkong i Makau/Aomen. Nie można wykluczyć, że przy tej okazji będziemy mieli jeszcze jeden pokaz chińskiej kreatywności w rozwiązywaniu problemów. Z pewnościa jednak Pekin nie zrezygnuje ze swych ambitnych celów. Tylko jakiś kataklizm na scenie wewnętrznej lub międzynarodowej mógłby pociągnąć za sobą zmianę czy korektę nakreślonej strategii. Jej efekt jest bowiem godzien największych poświęceń: ChRL bez Tajwanu to Chiny komunistyczne, ludowe czy lądowe, natomiast ChRL z Tajwanem to nowe mocarstwo ${ }^{84}$. O to właśnie toczy się gra, to jest „chińska stawka” proponowana teraz całemu światu.

W tej stawce jest jeszcze jedna, tym razem już geostrategiczna rozgrywka, zaproponowana światu przez Xi Jinpinga jesienią 2013 r. Najpierw podczas wykładu w Astanie, a następnie podczas konferencji na Bali w Indonezji zaproponował on jeszcze jeden powrót do chińskiej starożytności, tym razem w postaci budowy nowych jedwabnych szlaków, jakie kiedyś łączyły Państwo Środka z Zachodem, czyli Europa, ale też regionem rozumianym obecnie jako Bliski Wschód. Tak narodziła się inicjatywa, później nazwana łącznie jako Yi dai, Yi lu (Jeden Pas, Jeden Szlak), bowiem pierwszy, lądowy nazwano Ekonomicznym Pasem Jedwabnego Szlaku, a drugi Morskim Szlakiem XXI Stulecia ${ }^{85}$. Tak narodziła się koncepcja znana później jako OBOR (ang. One Belt, One Road).

Jest to przedsięwzięcie niezwykle śmiałe, wpisujące się już nie tylko w strategię, ale wręcz geostratgię. Nie wiadomo, czy przywódcy chińscy formułujący ten program sięgali do ojców geostrategii, ale jest faktem, że ekonomiczny pas na lądzie pokrywa się ze znanym pojęciem Heartland, sformułowanym przez ojca geostrategii Harolda MacKindera, natomiast Morski Szlak XXI Stulecia pokrywa się z kolei z Rimland Nicholasa Spykmana ${ }^{86}$, co przyznają nawet niektórzy autorzy chińscy ${ }^{87}$. OBOR jest największym projektem geostrategicznym od czasu zakończenia II wojny światowej, zakrojonym na wielką skalę (w tej chwili uczestniczy

83 B. Góralczyk, Chińska klasa średnia wkeracza na scene, „Obserwator Finansowy”, 16.09.2016, https://www.obserwatorfinansowy.pl/tematyka/makroekonomia/chinska-klasa-srednia-wkracza-na-scene/ (dostęp: 30.12.2016).

84 B. Góralczyk, Chinski feniks. Paradoksy wschodzacego mocarstwa, Warszawa 2010, s. 305.

85 Chiny za wyjątkiem przełomu XV i XVI stulecia i czasów admirała Zheng He, który docierał nawet do wybrzeży Afryki, nigdy mocarstwem morskim nie były, a teraz najwyraźniej chcą nim być.

86 Szerzej na ich temat: J. Bartosiak, Pacyfik i Eurarja. O wojnie, Warszawa 2016, s. 70, 71.

87 Xin Zhang, Chinese Capitalism and the New Silk. Roads, "Aspen Review. Central Europe" 2016, no. 4 , s. 28. 
w nim ponad 65 państw) i niezwykle kosztownym, a przy tym obudowywanym innymi instytucjami, jak Fundusz Rozwoju OBOR czy powołany do życia w czerwcu 2015 r. azjatycki z nazwy, ale chiński z zasobów i natury Azjatycki Bank Inwestycji Infrastrukturalnych (Asia Infrastructure Investment Bank - AIIB) ${ }^{88}$.

\section{Międzynarodowa reakcja}

OBOR jest strategią na tyle śmiałą i wizjonerską, że może wpłynąć na geostrategię i zmienić układ sił na świecie. Jest ważny dla Europy, bo oba szlaki, lądowy i morski, ku niej zmierzaja, a jeden $\mathrm{z}$ ważniejszych autorów chińskich nim się zajmujących, Wang Yiwei, nawet nie kryje chińskich celów, pisząc: „Ci, którzy mają Europę, maja świat" "89. Ten autor, uchodzący w ChRL za jednego z najważniejszych ekspertów zajmujących się OBOR, formułuje przy tym inne odważne tezy, niejako wcześniej kreślone przez Liu Mingfu. Jego zdaniem: „Celem tych działań jest uczynienie z Chin państwa, które dołączy do grona liderów globalnych. (...) Państwo Środka zmienia się zatem z uczestnika globalizacji w kraj, który nadaje jej ton"’0. Mamy więc do czynienia z projektem, który otwarcie podważa rolę i prymat dotychczasowego hegemona, czyli USA.

Nic dziwnego, że nowa asertywność pod wodzą piątej generacji z Xi Jinpingiem na czele wywołała wielką debatę na temat podejścia do Chin właśnie w USA, którą w literaturze polskiej znakomicie zreferował Jacek Bartosiak. Dotychczasowy hegemon, USA, napotkał bowiem na pretendenta do tronu, co prowadzi do zderzenia znanego już od starożytności, a nazwanego ostatnio w literaturze fachowej „pułapką Tukidydesa”. Jak wykazało specjalne badanie przeprowadzone na początku 2015 r. na Uniwersytecie Harvarda, z takiego zderzenia łatwo może dojść do otwartego konfliktu ${ }^{91}$. W przypadku Chin i USA terenem spornym jest przede wszystkim akwen Morza Południowochińskiego. Bez chińskiej kontroli nad nim trudno sobie wyobrazić realizację Morskiego Jedwabnego Szlaku. Tymczasem dotychczas akwen ten był kontrolowany przez flotę amerykańską, czasami przy wsparciu japońskiej. Tym samym mamy do czynienia z nową odsłoną konfliktu o kontrolę nad morzami i kontynentami na globie ${ }^{92}$.

${ }^{88}$ J. Szczudlik, Tryy lata Jedwabnego Szlaku: sukcesy i wyzwania, „Biuletyn PISM”, nr 73 (1423), 2.11.2016.

89 Wang Yiwei, Inicjatywa "Jeden Pas i Jedna Droga”. Co rozwój Chin oznacza dla świata, Toruń 2016, s. 15.

${ }^{90}$ Ibidem, s. 9, 10.

91 http://belfercenter.ksg.harvard.edu/publication/24928/thucydides_trap_case_file.html (dostęp: 2.01.2017).

92 J. Bartosiak, Pacyfik i Eurazja..., zwłaszcza rozdział Jak uniknaćpułapki Tukidydesa w stosunkach USA-Chiny, s. 559-570 
Bodaj najwnikliwiej nową chińską strategię i intencje „piątej generacji przywódców” odczytał Michael Pillsbury, od dekad zajmujący się Chinami w amerykańskim środowisku wywiadowczym i służb specjalnych. Pełen samokrytyki jako ten, który osobiście przyczynił się do zacieśniania dwustronnych stosunków z ChRL, bo najpierw zwalczano wspólnego wroga - ZSRR, a potem liczono, że reformujące się Chiny zliberalizują system polityczny, uważa on, że Państwo Środka zaproponowało USA i całemu światu ,stuletni maraton”. Dla niego nie ma już żadnych wątpliwości, że już rozpoczęła się walka o hegemonię. Pisze on: „Chińscy przywódcy przekonywali wielu na Zachodzie, że ich kraj będzie rósł pokojowo i nie kosztem innych

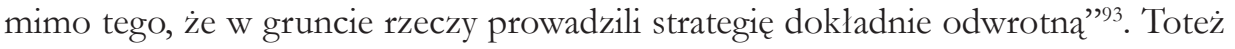
uważa, że w efekcie „mieliśmy do czynienia z najbardziej systematyczna, znacząca porażką wywiadu w całej amerykańskiej historii" ${ }^{94}$.

Nie mniej dramatyczne tezy na temat Chin stawia Peter Navarro, o tyle postać znacząca, że wskazana przez Donalda Trumpa jako osoba odpowiedzialna za kontakty z ChRL i handel (połączenie raczej nieprzypadkowe!) w nowej administracji. Ten związany z biznesem profesor Uniwersytetu Kalifornijskiego w Irvine w książce napisanej wspólnie z Gregiem Autry, a znamiennie zatytułowanej Śmierć spowodowana przez Chiny, przytacza cały katalog chińskich przewinień - od manipulacji handlowych i walutowych, poprzez zalewanie obcych rynków podróbkami, ataki hakerskie, aż po zanieczyszczenie środowiska czy szybkie budowanie własnej floty i potęgi militarnej. $\mathrm{Na}$ tej podstawie wzywa do przeciwdziałania i szybkiej reakcji ${ }^{95}$. Nic dziwnego, że w Pekinie przyjęto tę nominację z niepokojem, jeśli nie wręcz trwoga; zwłaszcza że prezydent elekt Donald Trump złamał dotychczasową tradycję i jako pierwszy od normalizacji stosunków z ChRL, czyli od 1 stycznia 1979 r., pozwolił sobie na przeprowadzenie rozmowy telefonicznej z prezydent Tajwanu, Tsai Ing-wen ${ }^{96}$.

Oczywiście, w społeczeństwie demokratycznym pojawiają się również inne głosy. Jedną z najlepszych rzeczowych analiz na temat aktualnych stosunków chińsko-amerykańskich oraz nowej roli ChRL na scenie globalnej, jeszcze przed wejściem na scenę trudno przewidywalnej, ale wyraźnie niechętnej Chinom administracji Trumpa, przedstawił były podsekretarz stanu ds. Azji Wschodniej Thomas J. Christensen. Jego zdaniem Chiny stanowią już niewątpliwie wyzwanie dla polityki amerykańskiej, ale nie sa jeszcze na tyle silne, by stanowić bezpośrednie zagrożenie dla

\footnotetext{
93 M. Pillsbury, The Hundred-Year Marathon. China's Secret Strategy to Replace America as the Global Superpower, New York 2016, s. 4.

94 Ibidem, s. 16.

95 P. Navarro, G. Autry, Death by China. Confronting the Dragon: A Global Call to Action, New Jersey 2011.

96 Zob. wymowny komentarz wpływowego chińskiego dziennika „Global Times” Unpresidented' Trump add fuel to fire, http://www.globaltimes.cn/content/1024366.shtml. Ocena sytuacji: http://wiadomosci.wp.pl/kat,36474,title,Donald-Trump-prowokuje-Chiny-Dojdzie-do-konfro ntacji-supermocarstw,wid,18621730, wiadomosc.html (dostęp: 2.01.2017).
} 
globalnej dominacji USA. Jednakże nowe ułożenie z nimi stosunków oraz stałe utrzymywanie strategicznego dialogu są ze wszech miar wskazane ${ }^{97}$.

Jeszcze bardziej niż prowadzący swój chłodny wywód Christiansen powatpiewa w nową chińską mocarstwowość jeden z najwybitniejszych zachodnich znawców współczesnych Chin, David Shambaugh ${ }^{98}$. Uważa on, że prowadzące bezprecedensową kampanie antykorupcyjną ${ }^{99}$ władze piątej generacji w istocie dokonują czystki wśród prawdziwych lub domniemanych przeciwników Xi Jinpinga, a równocześnie zmierzają ku coraz bardziej jednoosobowym rządom i większej autokracji niż spodziewana (na Zachodzie) liberalizacja. Ponieważ popełniły one - w którym to poglądzie Shambaugh nie jest bynajmniej odosobniony - pierwszy poważny błąd w całej epoce reform, od 1978 r., kiedy to wezwały obywateli ChRL do gry na giełdzie, chcąc szybciej dojść do zbudowania upragnionego „społeczeństwa umiarkowanego dobrobytu”, w efekcie zbudowały wielką bańkę na giełdach, która w czerwcu 2015 r. z hukiem pękła, powodując trzy krachy i straty szacowane na około bilion dolarów ${ }^{100}$. Co więcej, około $80 \mathrm{mln}$ obywateli Chin straciło swe oszczędności, a nierzadko dorobek życia. Spowodowało to, że stracili oni zaufanie do przywódców, co jest pierwszym takim przypadkiem od tragedii wokół placu Tiananmen wiosną 1989 r. Dlatego Shambaugh, doceniając wartość i głębokość chińskich zmian, mocno powattpiewa w dalsze sukcesy piątej generacji przywódców i pisze, że ,bez fundamentalnych i daleko idących zmian systemu politycznego chińska gospodarka pogrąży się w stagnacji”"101, a stąd wyłonią się kolejne problemy - polityczne, gospodarcze i socjalne.

Podobnie sceptyczne poglądy głoszą analitycy tej miary co wywodzący się z Hongkongu Willy Wo-Lap Lam czy uznawany za jednego z najwybitniejszych ekspertów europejskich Francois Godemont. Lam, na podstawie przeprowadzonej solidnej i wnikliwej analizy chińskiej sceny wewnętrznej ery Xi Jinpinga, stwierdza, że „Chiny są nadal mocno niestabilne”, a „chiński sen jest iluzoryczny”102. Godemont natomiast twierdzi, że „ambicja Xi wobec Chin jest fascynująca, ale w ostateczności może okazać się anachronizmem"103.

Raz jeszcze, jak wielokrotnie w przeszłości, oceny badaczy chińskich znajdują się w głębokiej sprzeczności z ocenami płynącymi z zewnątrz. Warto jednak zwrócić

${ }_{97}$ T.J. Christensen, The China Challenge. Shaping the Choices of a Rising Power, New York 2015.

98 D. Shambaugh, China's Future?, Cambridge, UK-Malden, Massachusetts 2016.

99 Jej ofiarami stali się generałowie i tak znani politycy, jak Bo Xilai czy Zhou Yongkang. Znakomita analiza zjawiska: Pin Ho, Wenguang Huang, Uderzenie w czerń. Morderstwo, pieniadze i walka o władze w Chinach, przeł. D. Cieśla-Szymańska, Wołowiec 2015.

${ }^{100}$ W efekcie, szacowane już na 4 bln USD rezerwy walutowe spadły w 2016 r. do sumy około 3,052 bln USD, http://www.tradingeconomics.com/china/foreign-exchange-reserves (dostęp: 2.01.2017).

${ }^{101}$ D. Shambaugh, China's Future..., s. 11.

${ }^{102}$ W. Wo-Lap Lam, Chinese Politics in the Era of Xi Jinping. Reneissance, Reform, or Retrogression?, New York 2015, s. 294.

${ }^{103}$ F. Godemont, Crego chca Chiny?..., s. 249. 
uwagę na to, że przewidywania Angusa Maddisona z początków tego stulecia nie tylko się sprawdziły, ale nawet zostały wyprzedzone. Ten wybitny ekonomista i statystyk wyliczał, że PKB Chin, liczony po kursie siły nabywczej pieniądza (Purchasing Power Parity - PPP), który w 1978 r., u progu reform, sięgał zaledwie 5\%, w 2005 r. powinien wynieść 15\%, a w 2030 - 23\% ${ }^{104}$. Tymczasem u progu 2017 r. Chiny już od ponad 3 lat są największą potęga gospodarcza po kursie PPP ${ }^{105}$, a ich udział w światowym PKB sięga 16,32\% ${ }^{106}$. Inne dostępne dane, nie mówiąc o chińskich, dowodza, że ten udział Państwa Środka w światowym handlu i gospodarce jest jeszcze większy, niż wynikałoby z danych tu przytoczonych.

\section{Zakończenie i wnioski}

U progu drugiej dekady XXI stulecia Chiny gruntownie zmieniły własną strategię, zarówno na arenie wewnętrznej, czemu tutaj poświęcono nieco mniej uwagi, jak i na arenie zewnętrznej, co jest głównym przedmiotem niniejszych rozważań. Z przeprowadzonej analizy jednoznacznie wynika, że mamy do czynienia z nowym globalnym graczem, który stawia przed sobą wiele ambitnych i dalekosiężnych zadań. Najpierw, do połowy 2021 r., chce zbudować u siebie klasę średnią, mającą stanowić podstawę nowego modelu rozwojowego. Potem, do końca roku 2049, ma być zakończony proces jednoczenia wszystkich ziem chińskich, prowadzony pod wzniosłymi hasłami „wielkiego renesansu chińskiej nacji”. Wszystko to dzieje się w momencie, gdy rodzi się chińska ekspansja na zewnątrz, wywołana nadprodukcją (towarów i kapitałów) u siebie oraz dość biernym, jak dotąd, odzewem narodu co do haseł budowania klasy średniej. Po części wynika to z tego, że wiara i zaufanie do władz zostały dość mocno zachwiane w trzech kolejnych krachach na chińskich giełdach od połowy 2015 do początków 2016 r. W ten sposób, jak słusznie pokazują obserwatorzy z zewnątrz (David Shambaugh, Willy Wo-Lap Lam czy Francois Godemont), pojawiły się kolejne niepewności i znaki zapytania co do przyszłości państwa i prowadzonych reform, na co władze odpowiedziały w sposób jeszcze bardziej autorytarny niż dotąd.

Piąta generacja przywódców z Xi Jinpingiem na czele nie tylko wykazuje większą asertywność i pewność siebie, płynącą z bezprecedensowych sukcesów gospodarczych Państwa Środka w ostatnich dekadach, ale też maluje zupełnie inny wizerunek Chin i ich zachowania na scenie globalnej, najbardziej widoczny w geostrategicznej

\footnotetext{
104 A. Maddison, Chinese Economic Performance..., s. 11.

105 Według danych Banku Światowego: PKB Chin na koniec 2015 r. wynosiło 19814369 mln USD, a USA - 18036648 mln USD, http:/ / data.worldbank.org/data-catalog/GDP-PPP-based-table (dostęp: 2.01.2017).

${ }^{106}$ Podczas gdy USA - 16,14\%, https://www.quandl.com/collections/economics/gdp-as-share-of-world-gdp-at-ppp-by-country (dostęp: 2.01.2017).
} 
wizji spod znaku One Belt One Road. Warto o nim wiedzieć więcej także u nas, bowiem tak się składa, że przynajmniej lądowa ścieżka Nowego Jedwabnego Szlaku prowadzi przez Polskę, a cały ten projekt jest skierowany geograficznie i inwestycyjnie ku Zachodowi i Europie, podczas gdy geostrategicznie stanowi wyzwanie dla dotychczasowego hegemona - USA.

Tym samym Chiny udowadniaja, że nie tylko odeszły od poprzedniej strategii Deng Xiaopinga, prezentującej je jako znajdujące się na dorobku największe państwo rozwijające się na świecie. Powoli odsłaniany po 2010 r., po części w wyniku własnych sukcesów gospodarczych, a po części z racji reakcji na światowy krach gospodarczy z 2008 r., wyłania się na scenie wizerunek stale rosnącego w siłę mocarstwa, mającego ambicje powrotu do świetności i renesansu ze swych najlepszych lat czy epok. Dzisiejsze Chiny nie są już państwem opowiadającym się za dotychczasowym status quo na arenie globalnej, lecz jak najbardziej przeobraziły się w siłe rewizjonistyczną, pragnącą wpłynąć na kształt nowego, ponownie wielobiegunowego porządku na globie. Tym razem - raz jeszcze, jak było do końca XVIII wieku - w porządku tym Państwo Środka zamierza wystapić w roli jednego z głównych na nim graczy. Dla Chińczyków to może być powrót do normalności, ale dla ludzi na Zachodzie to prawdziwy szok. Chiny nabrały znaczenia i tym bardziej trzeba się im uważnie przyglądać.

\section{SUMMARY}

\section{GEOSTRATEGY OF XI JINPING: FROM LOW PROFILE TO GLOBAL ASSERTIVENESS}

People's Republic of China (PRC), especially after 2010, partially in response to its unprecedented growth, and partially as the answer to the global crisis of 2008 , has recently started to change its internal model of development (crucial, but not in focus of this study), as well as its external strategy, which is the center of research here, and which in the form of One Belt, One Road (OBOR) vision is already a classical geostrategic case. The current leadership of the fifth generation with Xi Jinping as paramount leader has a blueprint: 1 . To create a middle class until 2021, 2. Of peaceful reunification with Taiwan; 3. Of the "great rejuvenation of Chinese nation" until October 2049. If successfully implemented, this strategy will definitely change not only China, but also the global landscape. This study is trying to explain what really has happened recently in PRC, why it has happened, and what is the meaning of those strategic changes in the Chinese leadership's approach both to PRC itself, and to the global arena. 